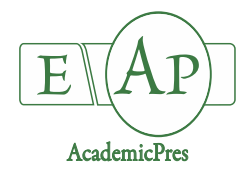

Tisarum R et al. (2020)
Notulae Botanicae Horti Agrobotanici Cluj-Napoca 48(4):1901-1914
DOI:10.15835/48412034
Research Article

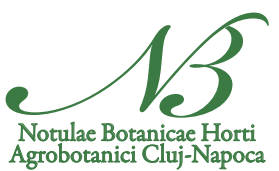

\title{
True-to-type micropropagated plants of para rubber (Hevea brasiliensis Müll. Arg.) via somatic embryogenesis
}

\author{
Rujira TISARUM ${ }^{1}$, Thapanee SAMPHUMPHUANG ${ }^{1}$, \\ Wittaya PROMMEE ${ }^{2}$, Chareerat MONGKOLSIRIWATANA ${ }^{3}$, \\ Suriyan CHA-UM ${ }^{1 *}$
}

\begin{abstract}
${ }^{1}$ National Center for Genetic Engineering and Biotechnology (BIOTEC), National Science and Technology Development Agency (NSTDA),PathumThaniThailand; rujira.tis@biotec.or.th; thapanee@biotec.or.th; suriyanc@biotec.or.th (*corresponding author) ${ }^{2}$ Chachoengsao Rubber Research Center, Rubber Research Institute, Chachoengsao Thailand; wittayastrc@hotmail.com ${ }^{3}$ Kasetsart University, Faculty of Liberal Arts and Science, Division of Genetics, Kampangsan Campus, Nakhon Pathom, Thailand; faascrp@ku.ac.th
\end{abstract}

\begin{abstract}
Plant micropropagation via somatic embryogenesis is a powerful technique for rapid mass propagation, especially in para rubber (Hevea brasiliensis Müll. Arg.). However, somaclonal variations are the major limitation of this process. To date, DNA fingerprinting, i.e., RAPD (Randomly Amplified Polymorphic DNA), Star Codon Targeted (SCoT), and SSRs (Simple Sequence Repeats), is one of the most successful technologies to detect the genetic fidelity in the somatic embryos. The aim of present study was to induce somatic embryos from inner integument explants of para rubber cv. 'RRIM 600' at different developmental stages and subsequent acclimatization and transplantation (under greenhouse and field conditions) of the propagated seedlings. The genetic stability of the plants derived from somatic embryos was also analysed in comparison to the mother plant using RAPD, SCoT and SSRs markers. Somatic embryos derived from inner integuments of 5-week-old immature seeds after pollination were more efficient than older and younger seeds. In addition, para rubber mother plants cv. 'RRIM600' and plants derived from somatic embryogenesis demonstrated the same pattern of DNA fragments, as confirmed by three PCR-based techniques, RAPD, SCoT and SSRs, whereas these in the pattern were different from 'RRIT 226, 'PB 235', 'PB 251', 'PB 255' and 'BMP 24'. Interestingly, T2 plant was found to possess somaclonal variations when compared with mother plant. Based on the results, we confirm that the plants derived from somatic embryogenesis of para rubber cv. 'RRIM 600' were true-to-type to that of 'RRIM 600' master stock.
\end{abstract}

Keywords: DNA fingerprinting; para rubber; RAPD; SCoT; SSRs

\section{Introduction}

Para rubber or rubber tree (Hevea brasiliensis Müll. Arg.) is an important economic crop of Southeast Asia, i.e., Thailand, Indonesia and Malaysia. It is cultivated in $\sim 9.7$ million hectares area in the region and contributes $97 \%$ of the world's natural rubber supply (Ratnasingam et al., 2015). According to the statistical 
report, global natural rubber consumption in the year 2019 was 12.119 megatons and it has been expected to increase at a rate of 16.5 megaton per year (IRSG, 2020). Maximum consumption of natural rubber has been reported in the tires of automobiles, which utilizes $\sim 70 \%$ of the total production, and its demand has been predicted to increase by 30 megatons per year by the year 2030 (Cornish, 2017). The para rubber planting area is rapidly expanding into the Montane Mainland Southeast Asia including Grate Mekong Subregion (China, Vietnam, Thailand, Laos, Myanmar and Cambodia) (Golbon et al., 2018; Yang et al., 2019) and Peninsular Malaysia (Hazir et al., 2020).

Para rubber cv. 'RRIM600' is a good candidate for plantation in Thailand and China with adaptation to drought, chilling and frost injuries and moderate yield (Priyadarshan et al., 2005; Gonçalves et al., 2011; Pethin et al., 2015; Yang et al., 2019). Elite clones of para rubber with high yield of latex, rapid growth, longlifetime tapping (20-30 years) and disease-resistant traits being developed through breeding programs (Supriya et al., 2019). Rootstock grafting with elite scion genotype is a common protocol to generate master stock of para rubber for small holder farmers in both Thailand ( $>85 \%$ of the total area; Chantuma et al., 2011) and Malaysia (>93\% of the total area; Hazir et al., 2020), which are the major plantation areas. Recently, the limitation of cross-talking (grafting efficiency) between rootstock and scion has been found to significantly affect the latex yield and growth rate of scion (Gonçalves and Martins, 2002; Cardinal et al., 2007; Yao et al., 2017) and to induce DNA methylation (epigenetic changes) in heterografted plants (Uthup et al., 2018). Selfrooted para rubber is an alternative way for elite clonal propagation ( $75 \%$ success rate from shoots to mature rooted plants) at the commercial scale to produce large number of healthy plants by cuttings (Masson and Monteuuis, 2016). Microcutting (Kalawong et al., 2014) and nodal segment micropropagation (Sirisom and Te-chato, 2014) via in vitro culture are the other alternatives. However, the vegetatively propagated plants lack taproot system, which makes it susceptible to wind disasters (Masson et al., 2013; Masson and Monteuuis, 2017). Somatic embryogenesis may overcome this problem, as it produces large number of plantlets containing tap root system, similar to the seedlings produced by seed germination (Zhao et al., 2015; Rahman et al., 2017; Wang et al., 2017). Recently, somatic embryos have been successfully developed from inner integuments of immature seeds and uninucleate anthers of male flower (Srichuay et al., 2014; Lardet et al., 2008; Kouassi et al., 2018; Tisarum et al., 2018). However, success of somatic embryogenesis in para rubber depends on genotype, and there are risks associated with in vitro acclimatization, somaclonal variation and high cost of production (Masson and Monteuuis, 2016; Tisarum et al., 2018).

True to type somatic embryos of para rubber, without somaclonal variation, are required for large scale production of elite clones (Wang et al., 2017). Based on this requirement, genetic and epigenetic changes have been studied in para rubber using molecular markers [including randomly amplified polymorphic DNA (RAPD) and simple sequence repeats (SSRs)] and DNA methylation [including methylation-sensitive amplification polymorphism (MSAP)] (Karumamkandathil et al., 2015; Wang et al., 2017). RAPD and SSRs are a simple, rapid, reproducible, and costly techniques to identify the genetic similarity in both intergeneric and intrageneric diversity (Thakur et al., 2016; Rohela et al., 2019). SCoT (start codon targeted marker) is a novel technique to confirm homogeneity of micropropagated plantlets derived from organogenesis or embryogenesis. In addition, two or three molecular markers, confirming genetic stability, have been well established in many plant species (Bhattacharyya et al., 2017a,b; Sharma et al., 2019). The aim of present study was to induce somatic embryos from inner integuments of para rubber cv. 'RRIM 600' at different developmental stages and subsequent acclimatization and transplantation (under greenhouse and field conditions) of the propagated seedlings. The genetic stability of the plants derived from somatic embryos was also analysed in comparison to the mother plant using RAPD, SCoT and SSRs markers. 


\section{Materials and Methods}

\section{In vitro culture and acclimatization of plantlets}

Immature seeds of Hevea brasiliensis cv. 'RRIM' 600 in different ages, 4, 5 and 6 weeks were collected after pollination. These were dipped in $95 \%$ ethanol and burned for surface sterilization in aseptic clean bench. Thereafter, inner integuments of each seed were dissected as initial explants and inoculated on MH-IN medium (Carron et al., 1989) under dark conditions for $25 \mathrm{~d}$. Number of callus formed in MH-IN medium was recorded, and callus induction percentage in each treatment was calculated. Callus derived from inner integuments were proliferated on MH-EXP medium for $25 \mathrm{~d}$ (Carron et al., 1989) and then embryogenic callus were induced using MH-EXP for $25 \mathrm{~d}$. Number of embryogenic callus in each treatment were counted. Somatic embryos derived from embryogenic callus inoculating on MH-DEN for $25 \mathrm{~d}$ (Carron et al., 1989) were induced. Embryos and elongated embryos from single somatic embryos were induced by MH-MAT and MH-GER medium for $25 \mathrm{~d}$ (Carron et al., 1989), respectively. Para rubber plantlets derived from somatic embryos were transferred to test tube containing MH-PL medium with activated charcoal $\left(1.5 \mathrm{~g} \mathrm{~L}^{-1}\right)$ and kept for $25 \mathrm{~d}$. The whole process of in vitro culture system of para rubber is demonstrated in Figure S1. In vitro acclimatization (Figure S2) and ex vitro adaptation (Figure S3) were practiced by following the method given by Tisarum et al. (2018) as along with 1.5 year-field trial (Figure S3).

\section{DNA extraction}

Leaf samples of three master stocks (mother plants) of para rubber cv. 'RRIM 600', nine in vitro acclimatized plantlets (Figure 1A), ten plants derived from somatic embryogenesis transplanted in the field for 1.5 year (Figure 1B) and an individual master stock of other cultivars, i.e., 'RRIT 226', 'RRIT 251', 'PB 235', 'PB 255' and 'BPM 24' were collected (Table 1). DNA was extracted using genomic DNA Mini Kit (Plant) (GP100, Geneaid ${ }^{\mathrm{TM}}$, Geneaid Biotech Ltd., South Korea) according to company protocol. In brief, $50 \mathrm{mg}$ of leaf tissues were ground using liquid nitrogen, transferred to $1.5 \mathrm{~mL}$ plastic tube, mixed with $400 \mathrm{~mL}$ GPX1 buffer containing $5 \mathrm{~mL}$ RNase A (mixed by vortex) and incubated at $60^{\circ} \mathrm{C}$ for $15 \mathrm{~min}$ (invert the tube $5 \mathrm{~min}$ interval). Thereafter, $100 \mathrm{~mL}$ GP2 buffer was added, mixed by vortex and then incubated on ice for $3 \mathrm{~min}$. Solution was filtered through filter column, centrifuged at $12,000 \times g$ for $2 \mathrm{~min}$. The filter column was discarded, and supernatant was collected and transferred to a new $1.5 \mathrm{~mL}$ plastic tube to which 1.5 volume GP3 buffer was added, and immediately mixed with vortex for $5 \mathrm{~s}$ and filtered through GD column. The extracted solution was centrifuged at $12,000 \times g$ for $2 \mathrm{~min}$, and added with $400 \mathrm{~mL} \mathrm{W1}$ buffer, then again centrifuged at $12,000 \times g$ for $30 \mathrm{~s}$, and added with $400 \mathrm{~mL}$ absolute ethanol (wash buffer), and again centrifuged at $12,000 \times g$ for 30s. After discarding the flow-through, the GD column was placed in the $1.5 \mathrm{~mL}$ collection tube and centrifuged at $12,000 \times g$ for $3 \mathrm{~min}$ to dry the column. Dry GD column was moved to a new $1.5 \mathrm{~mL}$ plastic tube, $150 \mathrm{~mL}$ pre-heated elution buffer $\left(10 \mathrm{mM}\right.$ Tris- $\mathrm{HCl}, \mathrm{pH} 8.5$ at $\left.60^{\circ} \mathrm{C}\right)$ to the centre of the column matrix, incubated at room temperature for $5 \mathrm{~min}$, centrifuged at 12,000×g for $1 \mathrm{~min}$, and then the purified DNA was collected and incubated at $-20^{\circ} \mathrm{C}$ for further assay.

Table 1. List of para rubber (Hevea brasiliensis) plant samples, code and descriptive information

\begin{tabular}{|c|c|l|c|}
\hline Sample & Code & Descriptive information & Symbol \\
\hline 1 & $600 / 1$ & RRIM 600 master stock 1 & 1 \\
\hline 2 & $600 / 2$ & RRIM 600 master stock 2 & 2 \\
\hline 3 & $600 / 3$ & RRIM 600 master stock 3 & T1 \\
\hline 4 & 600 tissue $/ 1$ & RRIM 600 in vitro plantlet \# 1 & T2 \\
\hline 5 & 600 tissue/2 & RRIM 600 in vitro plantlet \#2 & T3 \\
\hline 6 & 600 tissue/3 & RRIM 600 in vitro plantlet \#3 & T4 \\
\hline 7 & 600 tissue/4 & RRIM 600 in vitro plantlet \#4 & \\
\hline
\end{tabular}


Tisarum R et al. (2020). Not Bot Horti Agrobo 48(4):1901-1914

\begin{tabular}{|c|c|c|c|}
\hline 8 & 600 tissue $/ 5$ & RRIM 600 in vitro plantlet \#5 & T5 \\
\hline 9 & 600 tissue $/ 6$ & RRIM 600 in vitro plantlet \#6 & T6 \\
\hline 10 & 600 tissue $/ 7$ & RRIM 600 in vitro plantlet \#7 & $\mathrm{T} 7$ \\
\hline 11 & 600 tissue $/ 8$ & RRIM 600 in vitro plantlet \#8 & T8 \\
\hline 12 & 600 tissue $/ 9$ & RRIM 600 in vitro plantlet \#9 & T9 \\
\hline 13 & RRIM 600/1 & RRIM 600 transplanted plant in the field trial \# 1 & $\mathrm{R} 1$ \\
\hline 14 & RRIM 600/2 & RRIM 600 transplanted plant in the field trial \#2 & $\mathrm{R} 2$ \\
\hline 15 & RRIM 600/3 & RRIM 600 transplanted plant in the field trial \#3 & R3 \\
\hline 16 & RRIM 600/4 & RRIM 600 transplanted plant in the field trial \#4 & $\mathrm{R} 4$ \\
\hline 17 & RRIM 600/5 & RRIM 600 transplanted plant in the field trial \#5 & R5 \\
\hline 18 & RRIM 600/6 & RRIM 600 transplanted plant in the field trial \#6 & R6 \\
\hline 19 & RRIM 600/7 & RRIM 600 transplanted plant in the field trial \#7 & R7 \\
\hline 20 & RRIM 600/8 & RRIM 600 transplanted plant in the field trial \#8 & $\mathrm{R} 8$ \\
\hline 21 & RRIM 600/9 & RRIM 600 transplanted plant in the field trial \#9 & R9 \\
\hline 22 & RRIM 600/11 & RRIM 600 transplanted plant in the field trial \#11 & R11 \\
\hline 23 & RRIT 226 & RRIT 226 master stock & 226 \\
\hline 24 & RRIT 251 & RRIT 251 master stock & 251 \\
\hline 25 & PB 235 & PB 235 master stock & 235 \\
\hline 26 & PB 255 & PB 255 master stock & 255 \\
\hline 27 & PBM 24 & PBM 24master stock & 24 \\
\hline
\end{tabular}
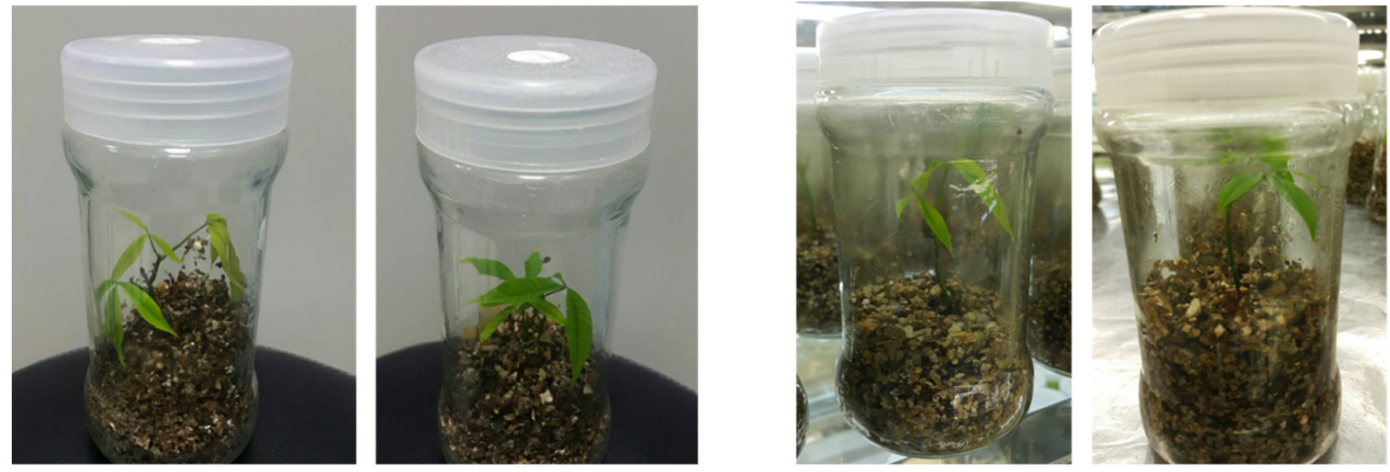

(A)

\section{In vitro plantlets}
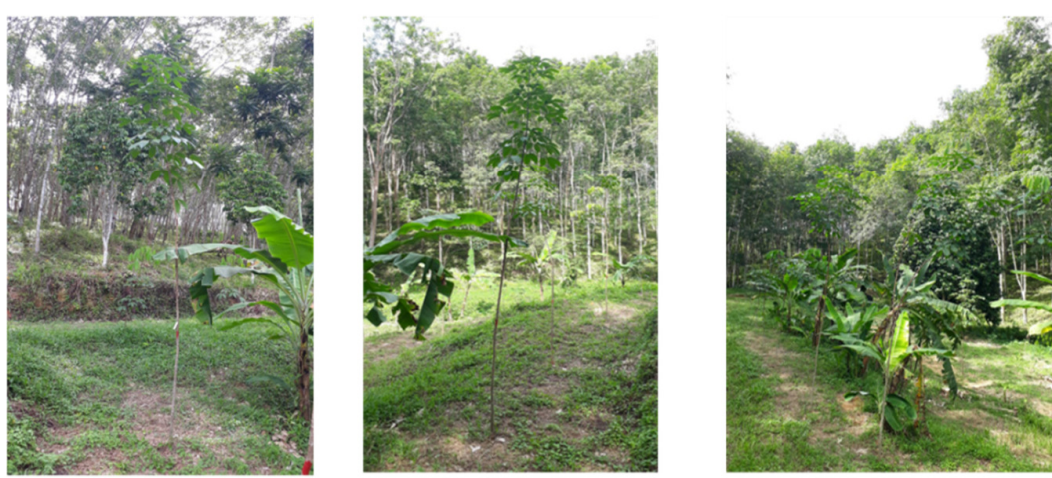

(B)

\section{Field trial plants}

Figure 1. In vitro plantlets in acclimatization stage before transplanting into soil (A) and the field trial para-rubber (Hevea brasiliensis) plants (1.5-year-old) derived from somatic embryogenesis 


\section{RAPD fidelity assay}

Extracted DNA ( $\left.50 \mathrm{ng} \mathrm{mL}^{-1}\right)$ from each sample $(3.2 \mathrm{~mL}$ ) was mixed with $1.2 \mathrm{~mL}$ deoxynucleotide (2 $\mathrm{mM}$ dNTPs mixture of dATP, dGTP, dCTP and dTTP; N0477s, New England Biolab Inc., MA, USA), 2 mL primers ( $5 \mathrm{mM}$ ) (30 RAPD primers; Table S1), $2 \mathrm{~mL}$ 10X PCR buffer, $0.16 \mathrm{~mL}$ Taq DNA polymerase (5 U $\mathrm{mL}^{-1}$; M0273s, New England Biolab Inc., MA, USA) and $11.44 \mathrm{~mL}$ deionized water (total volume $20 \mathrm{~mL}$ ). Mixture was amplified using PCR equipment (Mastercycler ${ }^{\circledR}$ nexus GX2, Eppendorf, NY, USA), denaturing at $95^{\circ} \mathrm{C}$ for 30s, annealing at $50^{\circ} \mathrm{C}$ for $1 \mathrm{~min}$, and extension at $68^{\circ} \mathrm{C}$ for $90 \mathrm{~s}$ with 40 cycles and extension at $68^{\circ} \mathrm{C}$ for $10 \mathrm{~min}$ in the final cycle. Agarose gel electrophoresis (1.8\%) with $1 \mathrm{X}$ TBE buffer (Amresco ${ }^{\circledR} 0478$ 40L Buffer, AMRESCO, Inc., OH, USA) was run along with 2 log DNA Ladder (M3200s, New England Biolab Inc., MA, USA), strained with ethidium bromide for $5 \mathrm{~min}$, washed by water for $3 \mathrm{~min}$ and visualized using Gel Documentation System (Bio-Rad Laboratories, Inc., CA, USA) (Figure S4). The presence (1) or absence (0) of band of target product DNA was scored for generating genetic similarity dendrogram according to Jaccard (1901) by UPGMA (unweight pair group method arithmetic average) using NTSYSpc 2.1 software.

\section{SCoT fidelity assay}

Extracted DNA ( $\left.50 \mathrm{ng} \mathrm{mL}^{-1}\right)$ from each sample $(3.2 \mathrm{~mL}$ ) was mixed with $1.2 \mathrm{~mL}$ deoxynucleotide (2 $\mathrm{mM}$ dNTPs mixture of dATP, dGTP, dCTP and dTTP; N0477s, New England Biolab Inc., MA, USA), $2 \mathrm{~mL}$ primers ( $5 \mathrm{mM}$ ) (15 SCoT primers; Table S2), $2 \mathrm{~mL}$ 10X PCR buffer, $0.16 \mathrm{~mL}$ Taq DNA polymerase (5 U $\mathrm{mL}^{-1}$; M0273s, New England Biolab Inc., MA, USA) and $11.44 \mathrm{~mL}$ deionized water (total volume $20 \mathrm{~mL}$ ). Mixture was amplified using PCR equipment (Mastercycler ${ }^{\circledR}$ nexus GX2, Eppendorf, NY, USA), denaturing at $94^{\circ} \mathrm{C}$ for $1 \mathrm{~min}$, annealing at $50^{\circ} \mathrm{C}$ for $1 \mathrm{~min}$, and extension at $68^{\circ} \mathrm{C}$ for 2 min with 35 cycles and extension at $68^{\circ} \mathrm{C}$ for $5 \mathrm{~min}$ in the final cycle. Agarose gel electrophoresis (1.8\%) with 1X TBE buffer (Amresco ${ }^{\circledR} 0478$ 40L Buffer, AMRESCO, Inc., OH, USA) was run along with 2 log DNA Ladder (M3200s, New England Biolab Inc., MA, USA), strained with ethidium bromide for $5 \mathrm{~min}$, washed by water for $3 \mathrm{~min}$ and visualized using Gel Documentation System (Bio-Rad Laboratories, Inc., CA, USA) (Figure S5). The presence (1) and absence (0) of band of target product DNA was scored for generating genetic similarity dendrogram according to Jaccard (1901) by UPGMA (unweight pair group method arithmetic average) using NTSYSpc 2.1 software.

\section{SSRs fidelity assay}

Extracted DNA (50 $\left.\mathrm{ng} \mathrm{mL}^{-1}\right)$ from each sample $(3.2 \mathrm{~mL})$ was mixed with $1.2 \mathrm{~mL}$ deoxynucleotide (2 mM dNTPs mixture of dATP, dGTP, dCTP and dTTP; N0477s, New England Biolab Inc., MA, USA), 2 mL primers ( $5 \mathrm{mM}$ ) (20 SSRs primers; Table S3), $2 \mathrm{~mL}$ 10X PCR buffer, $0.16 \mathrm{~mL}$ Taq DNA polymerase ( $5 \mathrm{U} \mathrm{mL}^{-}$ ${ }^{1}$; M0273s, New England Biolab Inc., MA, USA) and $11.44 \mathrm{~mL}$ deionized water (total volume $20 \mathrm{~mL}$ ). Mixture was amplified using PCR equipment (Mastercycler ${ }^{\circledR}$ nexus GX2, Eppendorf, NY, USA), denaturing at $94^{\circ} \mathrm{C}$ for 30 s, annealing at $52-57^{\circ} \mathrm{C}$ for 30 s, and extension at $72{ }^{\circ} \mathrm{C}$ for $1 \mathrm{~min}$ with 35 cycles and extension at $72{ }^{\circ} \mathrm{C}$ for $10 \mathrm{~min}$ in the final cycle. Polyacrylamide gel electrophoresis (6\%) with TBE buffer (Amresco ${ }^{\circledR} 0478-40 \mathrm{~L}$ Buffer, AMRESCO, Inc., OH, USA) was run along with DNA marker, strained with silver nitrate, washed by water for 3 min and visualized using Gel Documentation System (Bio-Rad Laboratories, Inc., CA, USA) (Figure S6). The presence (1) and absence (0) of band of target product DNA was scored for generating genetic similarity dendrogram according to Jaccard (1901) by UPGMA (unweight pair group method arithmetic average) using NTSYSpc 2.1 software.

\section{Experimental design and statistical analysis}

The experiment was arranged as completely randomized design (CRD) with 4 biological replications. Data were subjected to Analysis of variance (ANOVA) and mean values obtained from three treatments were compared using Tukey's HSD at $p \leq 0.01$ using SPSS software (version 11.5, SPSS for Window ${ }^{\circledR}$ ). 


\section{Results}

\section{Somatic embryogenesis derived from inner integuments of immature seeds}

Callus induction percentage of the inner integuments of 5-week-old immature seeds was maximum (52.9\%), with 160 explants per inoculum, on MH-IN as compared to younger (4-week-old; 38.9\%) and older (6-week-old; 28.3\%) seeds (Table 2 and Figure 2A). Highest embryogenic callus induction was also observed from the inner integuments of 5-week-old immature seeds (42.75\%) with 130 embryogenic callus on $\mathrm{MH}$ EXP, compared to younger (27.0\%) and older (12\%) seeds (Table 2 and Figure 2B). Moreover, somatic embryogenesis, embryos and plantlets derived from embryogenic callus were maximized at 33.3\%, $42.0 \%$ and $36.8 \%$, respectively when exposed to the culture medium, MH-DEN, MH-MAT and MH-PL, respectively (Table 2 and Figure 2 C-D). The plantlets were acclimatized for 3 months in the greenhouse conditions and thereafter, for 1.5 year under field conditions. The leaf samples collected from the plantlets derived from somatic embryogenesis were tagged as T1-T9 (Table 1 and Figure 1) and those collected from acclimatized plantlets were tagged as R1-R9 and R11 (Figure 1). Leaf samples were also collected to assay genetic fidelity of RRIM 600 original mother plant, 'RRIT 226', 'RRIT 251', 'PB 235', 'PB 255' and 'BPM 24 '.

Table 2. Callus induction, embryogenic callus, number of somatic embryos and plantlet regeneration in para rubber (Hevea brasiliensis) cv. 'RRIM 600' inner integument cultured on modified MH medium

\begin{tabular}{|c|c|c|c|c|c|}
\hline $\begin{array}{c}\text { Immature seeds } \\
\text { (weeks) }\end{array}$ & $\begin{array}{c}\text { Callus } \\
\text { induction } \\
(\%)\end{array}$ & $\begin{array}{c}\text { Embryogenic } \\
\text { callus } \\
(\%)\end{array}$ & $\begin{array}{c}\text { Somatic } \\
\text { embryos } \\
(\%)\end{array}$ & $\begin{array}{c}\text { Embryos } \\
(\%)\end{array}$ & $\begin{array}{c}\text { Plantlet } \\
\text { regeneration } \\
(\%)\end{array}$ \\
\hline 4 & $38.90 \pm 4.98 \mathrm{ab}$ & $27.00 \pm 2.58 \mathrm{~b}$ & $15.00 \pm 1.29 \mathrm{~b}$ & $14.25 \pm 1.22 \mathrm{~b}$ & $20.75 \pm 0.63 \mathrm{~b}$ \\
\hline 5 & $52.90 \pm 3.67 \mathrm{a}$ & $42.75 \pm 1.80 \mathrm{a}$ & $33.25 \pm 1.14 \mathrm{a}$ & $42.00 \pm 1.69 \mathrm{a}$ & $36.75 \pm 2.32 \mathrm{a}$ \\
\hline 6 & $28.25 \pm 2.08 \mathrm{~b}$ & $12.00 \pm 1.29 \mathrm{c}$ & $7.26 \pm 1.19 \mathrm{c}$ & $6.33 \pm 0.85 \mathrm{~b}$ & $10.75 \pm 1.71 \mathrm{c}$ \\
\hline Significant level & $* *$ & $* *$ & $* *$ & $* *$ & $* *$ \\
\hline
\end{tabular}

Different letters in each column show significant difference at $p \leq 0.01(* *)$ according to Tukey's HSD.

Data presented as mean \pm SE.
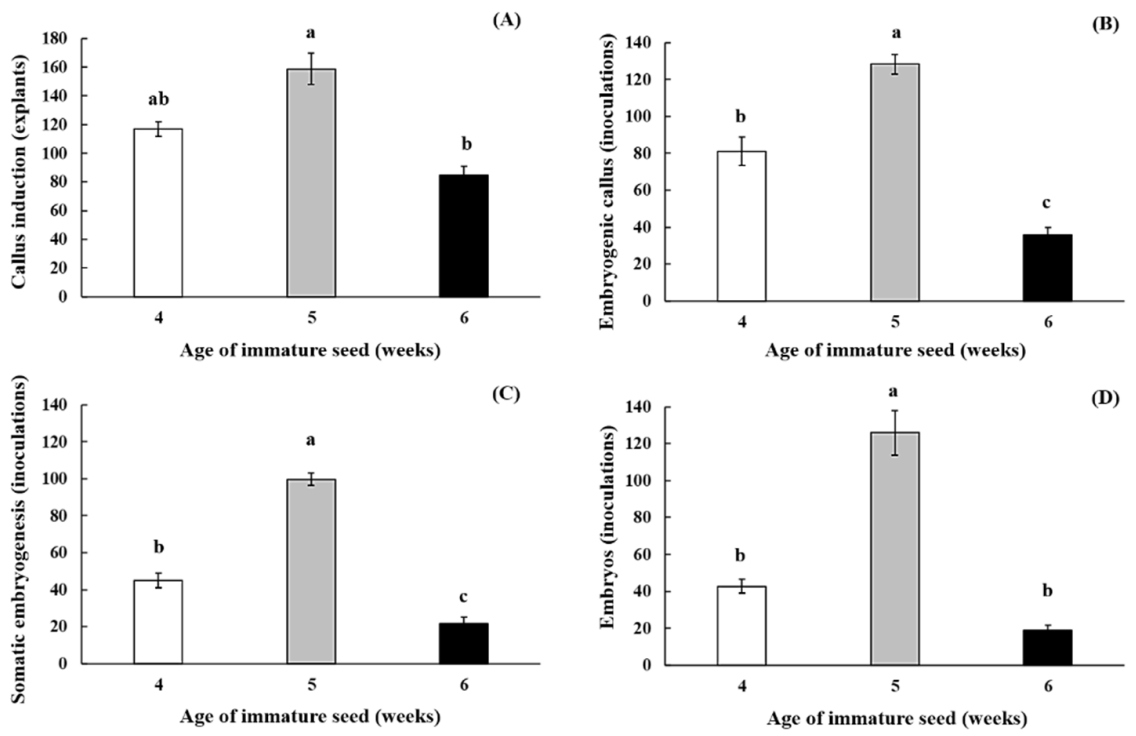

Figure 2. A response of immature inner integuments in different ages of seed development in para-rubber (Hevea brasiliensis) for callus induction (A), embryogenic callus (B), somatic embryogenesis (C) and embryos induction (D) on modified $\mathrm{MH}$ medium

Data presented as mean \pm SE. Different letters in each bar show significant difference at $p \leq 0.01(* *)$ according to Tukey's HSD. 


\section{Genetic fidelity evaluation using RAPD, SCoT and SSRs}

Based on 30 RAPD markers, 406 bands (254 polymorphic bands and 152 monomorphic bands) were counted and used to draw a genetic similarity dendrogram using UPGMA. Similarity in DNA fingerprinting using RAPD in each plant (derived from plantlets produced under in vitro conditions, plants acclimatized under greenhouse conditions and plants transplanted under field conditions) was demonstrated (Table S4). Acclimatized plants \#1 (T1) and \#2 (T2) had low similarity (<0.840) to 'RRIM 600' original, \#1, \#2 and \#3 (Table S4). In addition, the similarity among plants derived from somatic embryogenesis and from 'RRIT 226', 'RRIT 251', 'PB 235', 'PB 255' and 'BPM 24' was quite less (Table S4). In cluster dendrogram, genetic stability in plantlets derived from somatic embryogenesis was in a similar pattern to that of 'RRIM 600' original, \#1, \#2 and \#3 (Cluster I), whereas T1 and T2 were categorized in Cluster II. Moreover, 'RRIT 226' (Cluster III), 'RRIT 251' (Cluster IV), 'PB 235', 'PB 255' (Cluster V) and 'BPM 24' (Cluster VI) were classified under different groups (Figure 3).

In 15 SCoT markers, 186 bands ( 51 polymorphic bands and 135 monomorphic bands) were detected and analysed for genetic similarity dendrogram using UPGMA. Acclimatized plants \#1 (T1) and \#2 (T2) showed a small difference in pattern $(<0.930)$ when compared with 'RRIM 600' original, \#1, \#2 and \#3 (Table S5). Therefore, the pattern of SCoT bands among plants derived from somatic embryogenesis was similar to that of RRIM 600 original and different from that of 'RRIT 226', 'RRIT 251', 'PB 235', 'PB 255' and 'BPM 24 ' (Table S5). Based on UPGMA cluster analysis, genetic fetidity in plantlets derived from somatic embryogenesis showed a similar pattern to 'RRIM 600' original, \#1, \#2 and \#3 (Cluster I), whereas T1 and T2 were categorized in Cluster II. Moreover, 'RRIT 226' (Cluster III), 'PB 235', 'PB 255' (Cluster IV), 'RRIT 251 '(Cluster V), and 'BPM 24' (Cluster VI) were identified as other clusters (Figure 4).

In our study, 20 SSR markers were used for genetic diversity assay (Table S6). Within the plantlets derived from somatic embryogenesis, low genetic diversity was noticed $(<4 \%)$ except in $\mathrm{T} 2$, which was different from RRIM 600 original (by $>20 \%$ ). Based on UPGMA cluster analysis, genetic stability in plantlets derived from somatic embryogenesis was evaluated in the same group with 'RRIM 600' original, \#1, \#2 and \#3 (Cluster I), except T2 being categorized in Cluster III. Moreover, 'RRIT 226' (Cluster II), 'PB 235' (Cluster IV), 'PB 255' (Cluster V), 'RRIT 251' and 'BPM 24' (Cluster VI) were classified under separate categories (Figure 5).

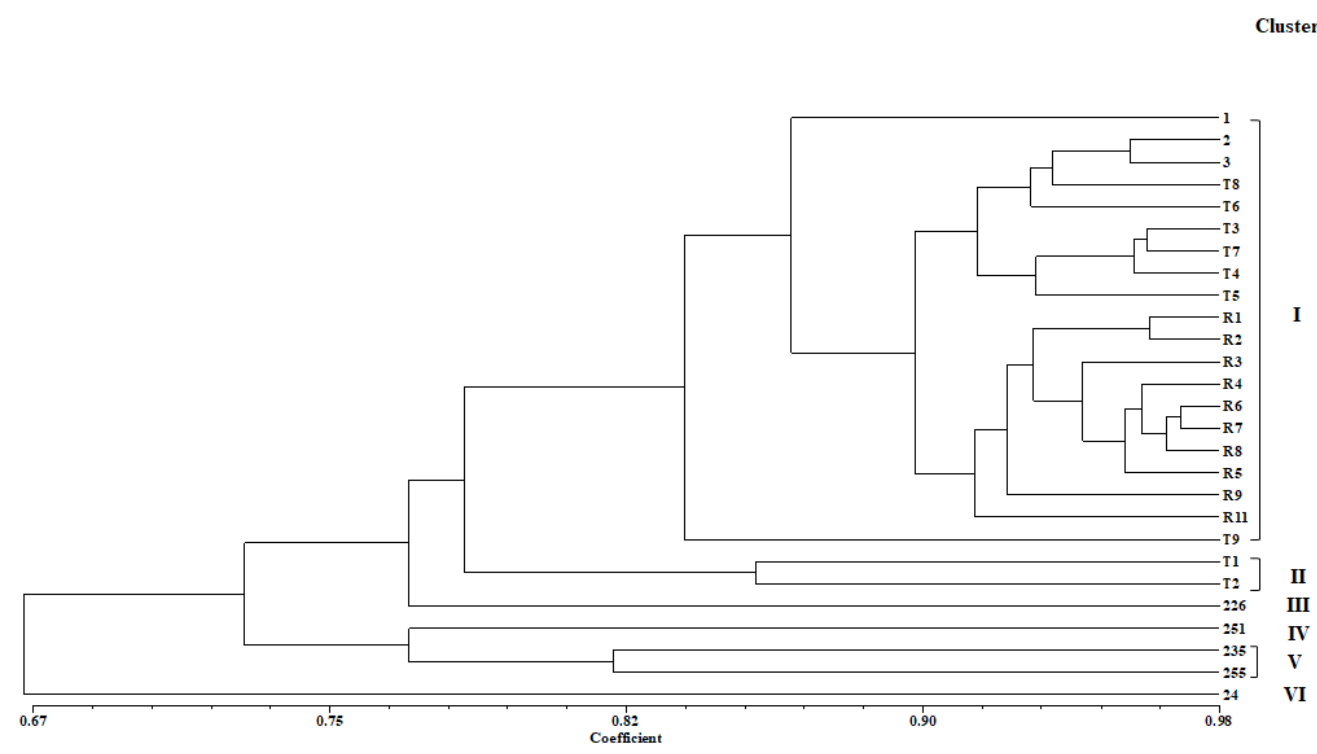

Figure 3. UPGMA (unweighted pair group method using arithmetic average) cluster analysis of para rubber (Hevea brasiliensis) based on RAPD method (30 primers) using NTSYSpc 2.1 


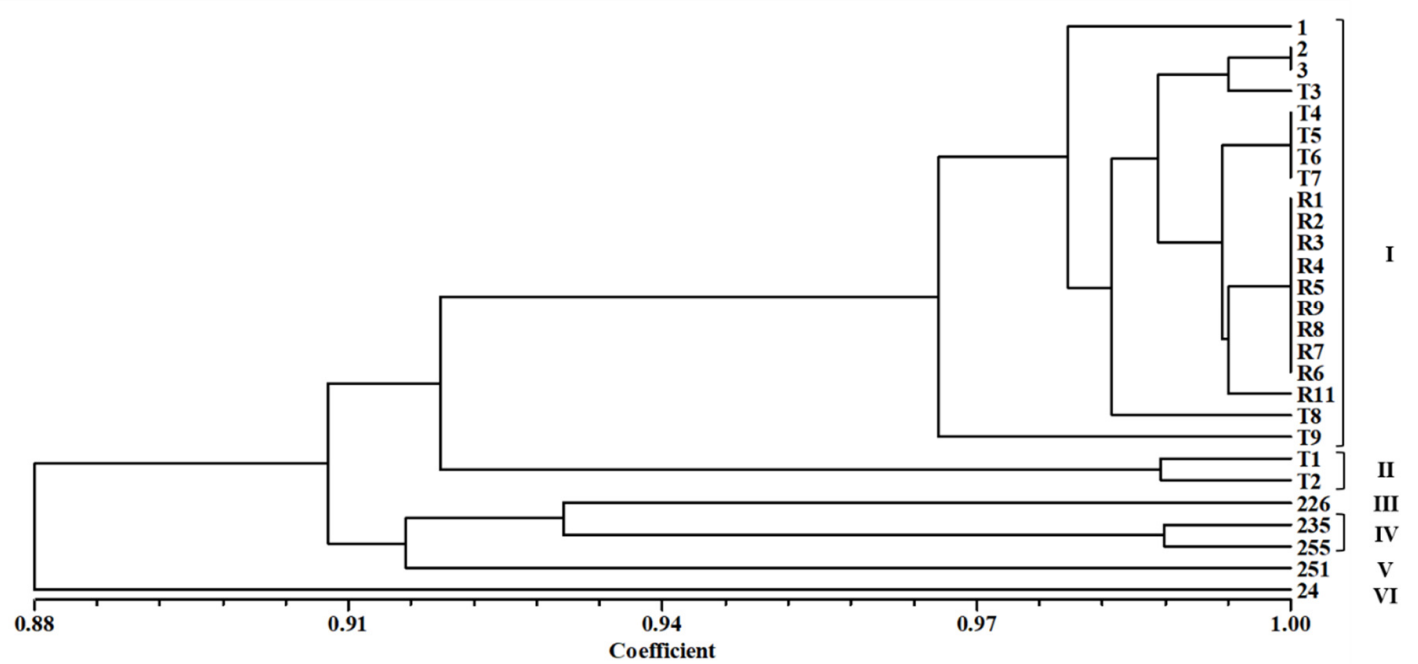

Figure 4. UPGMA (unweighted pair group method using arithmetic average) cluster analysis of para rubber (Hevea brasiliensis) based on SCoT method (15 primers) using NTSYSpc 2.1

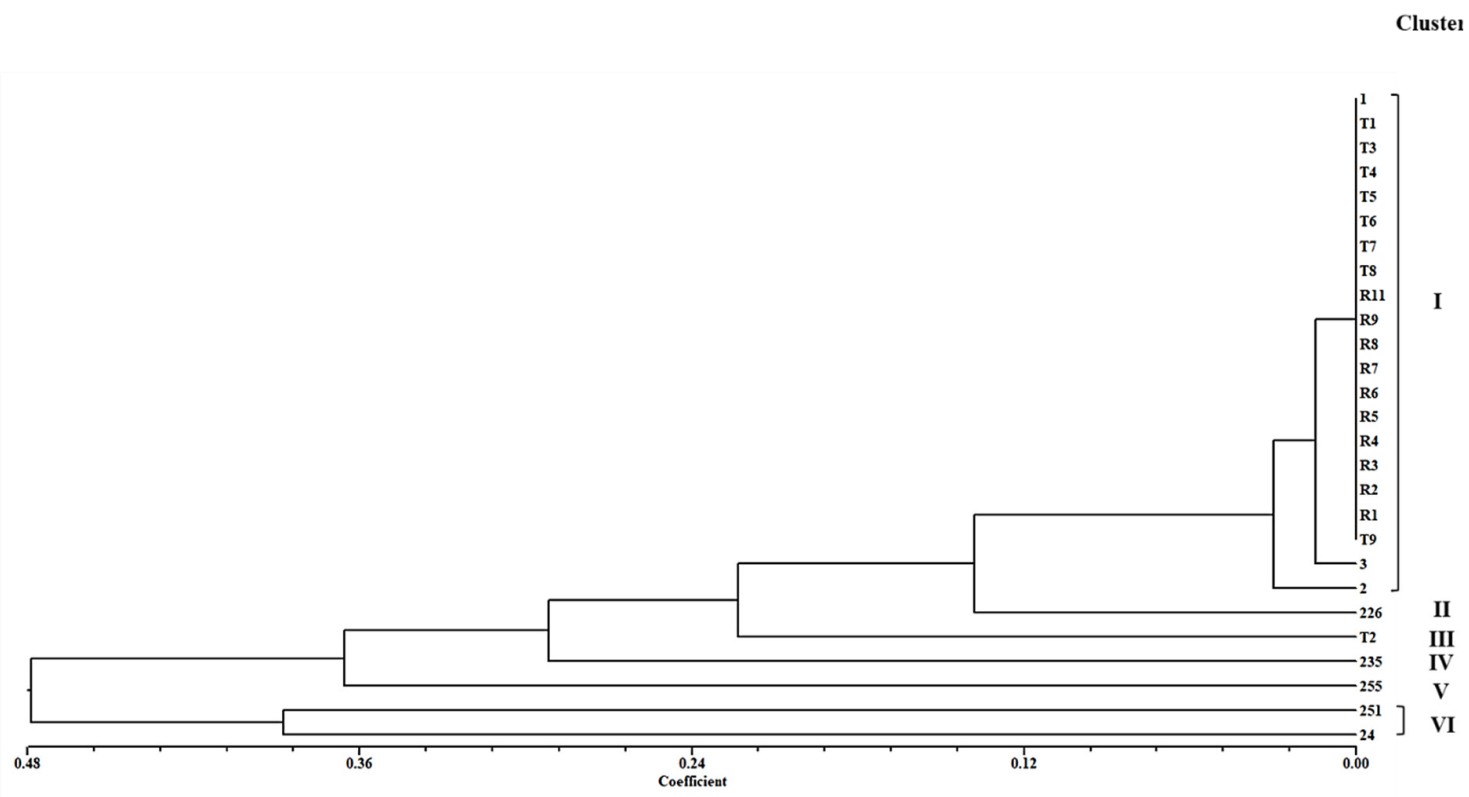

Figure 5. UPGMA (unweighted pair group method using arithmetic average) cluster analysis of para rubber (Hevea brasiliensis) based on SSRs microsatellite method (20 primers) using NTSYSpc 2.1

\section{Discussion}

Inner integuments of immature seeds (9-12-week-old after anthesis) of para rubber cvs. 'BT86', 'BT96' and 'EM96' have been successfully inoculated as initial explants on the MH-IN for callus induction, embryogenic callus induction, formation of somatic embryos and secondary somatic embryogenesis (Lardet et al., 2008). In para rubber cv. 'PB260', inner integuments of 10-week-old immature fruits was initially inoculated as explants for callus induction [MS $+9 \mathrm{mM}$ 2,4-dichlorophynoxy acetic acid (2,4-D) $+3.375 \mathrm{mM}$ 
Kinetin] and subsequently transferred to embryogenic callus induction and somatic embryogenesis (Modeste et al., 2013). Sucrose is an alternative factor to regulate callus induction (111 mM) and embryogenic callus induction (234 mM) in para rubber cv. 'PB 260' (Blanc et al., 2002; Modeste et al., 2012). The other sources of explants, i.e., protoplast (cell suspension) (Sushamakumari et al., 2000) and uninucleate anther (immature male flower bud) (Srichuay et al., 2014; Zhao et al., 2015; Wang et al., 2017) have been successfully inoculated for somatic embryogenesis. Somaclonal variations depend on i) presence of strong auxins [2,4-D and 3,4dichlorophenoxyacetic acid $(3,4-\mathrm{D})]$ in inoculated medium for embryogenic callus and somatic embryogenesis induction (Modeste et al., 2013), ii) genotypes/clones (Srichuay et al., 2014), and iii) secondary somatic embryogenesis (subculture cycles) that ensures genetic fidelity in each plant derived from somatic embryogenesis (Wang et al., 2017).

In para rubber, two RAPD makers, OPAA-07 and OPJ-19 were used to detect genetic viability of plant derived from zygotic polyembryony (Karumamkandathil et al., 2015). In African hyacinth (Ledebouria revoluta), 17 RAPD markers were used to confirm the genetic stability in plants derived from somatic embryogenesis (Haque and Ghosh, 2016). Ten RAPD markers were used to validate the genetic stability in plants derived from indirect regeneration of Rauwolfia tetraphylla L. (Rohela et al., 2019). Six selected lines of Echinacea purpurea derived from somatic embryogenesis were evaluated for their genetic stability using 10 RAPD markers (Lema-Rumińska et al., 2019). In contrast, about 20-30\% genetic variation using only one OPD-20 RAPD primer was detected in rough lemon (Citrus jambhiri Lush.) plantlets derived from somatic embryogenesis (Savita et al., 2015). In Withania coagulans, 12 RAPD markers were used to confirm genetic stability in shoot regenerated plants derived from indirect organogenesis of leaf explants (Rathore et al., 2016). Genetic homogeneity in micropropagated plants of Pitosporumerio carpum Royle was detected by 10 RAPD markers and the plantlets were clustered in the same group as that of donor mother plant (97\% similarity) (Thakur et al., 2016). Micropropagation via direct and indirect organogenesis in Rumex nepalensis has shown a less degree of variation within the clones when analyzed using 7 RAPD makers compared to 12 SCoT makers (Bhattacharyya et al., 2017a). Moreover, RAPD marker is suggested to be suitable for identifying the diversity in genetic resources of para rubber (Venkatachalam et al., 2004; Nakkanong et al., 2008; Liyanage et al., 2014).

This is the first report to apply SCoT markers for assessing genetic fidelity in para rubber micropropagation. In a previous study, high degree of genetic variation in plantlets of Rumex nepalensis, micropropagated via direct and indirect shoot organogenesis was detected by $12 \mathrm{SCoT}$ primers, whereas it was undetected using 7 RAPD markers (Bhattacharyya et al., 2017a). Genetic stability in 9 randomly propagated plants of Bauhinia racemosa using 18 SCoT makers was reported as true-to-type (Sharma et al., 2019). Similarly, micropropagated plants free of somaclonal variations (100\% similarity with mother plant), derived via indirect organogenesis were confirmed using SCoT markers in Helicteres isora (Muthukumar et al., 2016), Chrysanthemum morifolium and C. coccineum (Nasri et al., 2018) and Saccharum officinarum (Sathish et al., 2018). Similarity value ranged from $0.89-1.00$ in 9 individual plants derived from nodal segment micropropagation of Pittosporum eriocarpum tested using 10 SCoT primers (Thakur et al., 2016). Moreover, genetic fidelity of plantlets derived from indirect organogenesis of Rauwolfia tetraphylla was confirmed using 10 SCoT primers as true-to-type without any polymorphism (Rohela et al., 2019). Genetic similarity between somatic embryos and mother plants of Coffea arabica detected using 12 SCoT makers was found to be 0.987 (Bychappa et al., 2019). In medicinal orchid (Ansellia africana), 16 reproducible SCoT primers were applied to identify the genetic stability in first, second, and third generation of subculture which ranged from 0.95 to 1.00 as per Jaccard's similarity matrix and were presented in the same cluster as that of mother plants as per UPGA cluster analysis (Bhattacharyya et al., 2017b). Genetic stability of plantlets of Morus alba cv. 'Chinese', derived from indirect organogenesis was confirmed to be similar to the mother plant using $10 \mathrm{SCoT}$ primers (Rohela et al., 2020). In Nardostachys jatamansi, genetic variations in micropropagated plants was found to be dependent on the pathway of genesis of new plantlets as detected by 10 SCoT primers, with direct shoot organogenesis showing a variation of $4.38 \%$ from that of mother plant and indirect shoot organogenesis (showing a variation of $7.14 \%$ from that of mother plant) (Bose et al., 2016). Moreover, genetic stability of 
shoots proliferated from nodal segments of Alhagi maurorum was validated using 13 SCoT primers (Agarwal et al., 2015).

In para rubber clone CATAS7-33-97, variation of regenerated plants (2.61\% of mother plant) derived from secondary embryogenesis using 12 EST-SSR markers was observed (Wang et al., 2017). Somaclonal variation in callus culture of para rubber was detected by hmct 1 and hmc 5 SSR primers, whereas these ignored the variations in somatic embryos from somatic embryogenesis (Srichuay and Te-chato, 2015). In addition, in vitro plantlets derived from nodal culture of para rubber were confirmed as true-to-type without somaclonal variation by 3 SSR primers (Sirisom and Te-chato, 2014). In guava, genetic homogeneity in plants derived from somatic embryogenesis was validated by 6 SSR markers (Rai et al., 2012). Absence of somaclonal variations in the sesame plantlets, derived via indirect organogenesis was validated using 10 SSR markers (Anandan et al., 2018). In contrast, somaclonal variations in somatic embryogenesis-regenerated Spanish grapevine (Vitis vinifera) cv. 'Torrontés' were detected in a mutant allele (231) instead of the normal allele (237) at the locus VVMD5 by SSR microsatellite analysis (Prado et al., 2010). Moreover, somaclonal variations in olive plants derived from somatic embryogenesis was slightly higher in T1 lines (youngest lines; identified by lowest similarity coefficients) when compared with T2 and T4 based on SSR makers (Bradï et al., 2019).

\section{Conclusions}

In the present study, somatic embryogenesis was successfully carried out from the inner integuments of 5-week-old immature para rubber fruits. The plantlets were subsequently acclimatized under in-vitro, greenhouse and field conditions. Genetic fidelity was confirmed using RAPD, SCoT and SSRs markers. It was concluded that the somaclonal variation is present only in one plant (T2) as detected by RAPD, SCoT and SSR markers (PCR-based rapid detection). Based on this investigation, a thorough research on the genetic variations in T2 plants compared to wild type 'RRIM 600' is suggested.

\section{Authors' Contributions}

Conceptualization, supervision, validation, visualization, writing - original draft, writing - review and editing: SC and WP; Methodology, data curation and analysis, RT, JM and TS.

All authors read and approved the final manuscript.

\section{Acknowledgements}

The authors would like to sincerely thank Rubber Research Institute of Thailand, Ministry of Agricultural and Cooperative, for plant material source. This research received no specific grant from any funding agency in the public, commercial, or not-for-profit sectors.

\section{Conflict of Interests}

The authors declare that there are no conflicts of interest related to this article. 
Tisarum R et al. (2020). Not Bot Horti Agrobo 48(4):1901-1914

\section{References}

Agarwal T, Gupta AK, Patel AK, Shekhawat NS (2015). Micropropagation and validation of genetic homogeneity of Alhagi maurorum using SCoT, ISSR and RAPD markers. Plant Cell, Tissue and Organ Culture 120:313-323. https://doi.org/10.1007/s11240-014-0608-Z

Anandan R, Prakash M, Deenadhayalan T, Nivetha R, Kumar NS (2018). Efficient in vitro plant regeneration from cotyledon-derived callus cultures of sesame (Sesamum indicum L.) and genetic analysis of true-to-type regenerants using RAPD and SSR markers. South African Journal of Botany 119:244-251. https://doi.org/10.1016/j. sajb.2018.09.020

Bhattacharyya P, Kumaria S, Bose B, Paul P, Tandon P (2017a). Evaluation of genetic stability and analysis of phytomedicinal potential in micropropagated plants of Rumex nepalensis-A medicinally important source of pharmaceutical biomolecules. Journal of Applied Research on Medicinal and Aromatic Plants 6:80-91. https://doi.org/10.1016/j.jarmap.2017.02.003

Bhattacharyya P, Kumar V, van Staden J (2017b). Assessment of genetic stability amongst micropropagated Ansellia africana, a vulnerable medicinal orchid species of Africa using SCoT markers. South African Journal of Botany 108:294-302. https://doi.org/10.1016/j.sajb.2016.11.007

Blanc G, Lardet L, Martin A, Jacob JL, Carron MP (2002). Differential carbohydrate metabolism conducts morphogenesis in embryogenic callus of Hevea brasiliensis (Müll. Arg.). Journal of Experimental Botany 53:1453-1462. https://doi.org/10.1093/jexbot/53.373.1453

Bose B, Kumaria S, Choudhury H, Tandon P (2016). Assessment of genetic homogeneity and analysis of phytomedicinal potential in micropropagated plants of Nardostachys jatamansi, a critically endangered, medicinal plant of alpine Himalayas. Plant Cell, Tissue and Organ Culture 124:331-349. https://doi.org/10.1007/s11240-015-0897-X

Bradaï F, Sánchez-Romero C, Martín C (2019). Somaclonal variation in olive (Olea europaea L.) plants regenerated via somatic embryogenesis: Influence of genotype and culture age on genetic stability. Scientia Horticulturae 251:260-266. https://doi.org/10.1016.j.scienta.2019.03.010

Bychappa M, Mishra MK, Jingade P, Huded AK (2019). Genomic alterations in coding region of tissue culture plants of Coffea arabica obtained through somatic embryogenesis revealed by molecular markers. Plant Cell, Tissue and Organ Culture 139:91-103. https://doi.org/10.1007/s11240-019-01666-8

Cardinal ÁBB., Gonçalves PDS., Martins, ALM (2007). Stock-scion interactions on growth and rubber yield of Hevea brasiliensis. Scientia Agricola 64:235-240. http://dx.doi.org/10.1590/S0103-90162007000300004

Carron MP, Enjalric F, Lardet L, Deschamps A (1989). Rubber (Hevea brasiliensis Müll. Arg.). In: Bajaj YPS (Eds.), Biotechnology in Agriculture and Forestry, vol. 5 Trees II, Springer, Berlin, Heidelberg. pp 222-245.

Chantuma P, Lacote R, Leconte A, Gohet E (2011). An innovative tapping system, the double cut alternative, to improve the yield of Hevea brasiliensis in Thai rubber plantations. Field Crops Research 121:416-422. https://doi.org/10.1016/j.fcr.2011.01.013

Cornish K (2017). Alternative natural rubber crops: why should we care? Technology and Innovation 18:244-255. https://doi.org/10.21300/18.4.2017.245

Golbon R, Cotter M, Sauerborn J (2018). Climate change impact assessment on the potential rubber cultivating area in the Greater Mekong Subregion. Environmental Research Letters 13:084002.

Gonçalves PS, Martins ALM (2002). Combining ability effects of clonal rootstocks and scions in rubber trees (Hevea). Crop Breeding and Applied Biotechnology 2:445-452.

Gonçalves PS, Scaloppi Jr EJ, Martins MA, Moreno RMB, Branco RBF, Gonçalves ECP (2011). Assessment of growth and yield performance of rubber tree clones of the IAC 500 series. Pesquisa Agropecuária Brasileira 46:16431649. https://doi.org/10.1590/S0100-204X2011001200009

Haque SM, Ghosh B (2016). High-frequency somatic embryogenesis and artificial seeds for mass production of true-totype plants in Ledebouria revoluta: An important cardioprotective plant. Plant Cell, Tissue and Organ Culture 127:71-83. https://doi.org/10.1007/s11240-016-1030-5

Hazir MHM, Kadir RA, Gloor E, Galbraith D (2020). Effect of agroclimatic variability on land suitability for cultivating rubber (Hevea brasiliensis) and growth performance assessment in the tropical rainforest climate of Peninsular Malaysia. Climate Risk Management 27:100203. https://doi.org/10.1016/j.crm.2019.100203

IRSG (International Rubber Study Group) (2020). Statistical Summary of World Rubber Situation (Singapore: International Rubber Study Group) (https://www.statista.com/statistics/275390/world-usage-distribution-ofnatural-rubber/) 
Jaccard P (1901). Étude comparative de la distribution florale dans une portion des Alpes et des Jura. Bull Soc Vandoise Sci Nat 37:547-579.

Kalawong S, Srichuay W, Sirisom Y, Te-chato S (2014). Microcutting as a tool for propagation and genetic transformation in rubber tree. Thaksin University Journal 17:15-25.

Karumamkandathil R, Uthup TK, Sankaran S, Unnikrishnan D, Saha T, Nair SS (2015). Genetic and epigenetic uniformity of polyembryony derived multiple seedlings of Hevea brasiliensis. Protoplasma 252:783-796. https://doi.org/10.1007/s00709-014-0713-1

Kouassi KM, Koffi KE, Gnagne M, Kone M, Kouakou TH (2013). Influence of plant growth regulators on somatic embryogenesis induction from inner teguments of rubber (Hevea brasiliensis) seeds. African Journal of Biotechnology 12:1972-1977. https://doi.org/10.5897/AJB12.2411

Lardet L, Dessailly F, Carron MP, Montoro P, Monteuuis O (2008). Influences of aging and cloning methods on the capacity for somatic embryogenesis of a mature Hevea brasiliensis genotype. Tree Physiology 29:291-298. https://doi.org/10.1093/treephys/tpn027

Lema-Rumińska J, Kulus D, Tymoszuk A, Varejão JM, Bahcevandziev K (2019). Profile of secondary metabolites and genetic stability analysis in new lines of Echinacea purpurea (L.) Moench micropropagated via somatic embryogenesis. Industrial Crops and Products 142:111851. https://doi.org/10.1016/j.indcrop.2019.111851

Liyanage KK, Sumanasinghe VA, Attanayake DPSTG, Baddewithana BWAN (2014). Identification of recommended Hevea brasiliensis (Willd. ex A. Juss.) Müll. Arg. clones grow in Sri Lanka by RAPD analysis. Tropical Agricultural Research 25:188-200.

Masson A, Julien JM, Boedt L (2013). Industrial propagation by rooted cuttings of mature selected clones of Hevea brasiliensis. Bois et Forêts des Tropiques 317:51-58.

Masson A, Monteuuis O (2016). Mass production of self-rooted Hevea brasiliensis industrial clones by tissue culture and nursery methods. Proceeding of the Fourth International Conference of the IUFRO Unit 2.09 .02 on Development and application vegetative propagation technologies in plantation forestry to cope with a changing climate and environment. September 19-23, 2016, La Plata, Argentina.

Masson A, Monteuuis O (2017). Rubber tree clonal plantations: grafted vs self-rooted plant material. Bois et Forêts des Tropiques 332:58-68.

Modeste KK, Edmond KK, Konkon NÃ, Miche, G, Hilaire KT (2012). Callogenesis and somatic embryogenesis induction in Hevea brasiliensis: Effects of fruit shelf-life and carbon source. Research in Biotechnology 3:42-50.

Muthukumar M, Kumar TS, Rao MV (2016). Organogenesis and evaluation of genetic homogeneity through SCoT and ISSR markers in Helicteres isora L., a medicinally important tree. South African Journal of Botany 106:204-210. https://doi.org/10.1016/j.sajb.2016.07.017

Nakkanong K, Nualsri C, Sdoodee S (2008). Analysis of genetic diversity in early introduced clones of rubber tree (Hevea brasiliensis) using RAPD and microsatellite markers. Songklanakarin Journal of Science and Technology 30:553-560.

Nasri F, Zakizadeh H, Vafaee Y, Mozafari AA (2018). Callus induction and plant regeneration of Chrysanthemum morifolium and $C$. coccineum via direct and indirect organogenesis and genetic fidelity analysis using IRAP, ISSR and SCoT molecular markers. Journal of Ornamental Plants 8:265-284.

Prado MJ, Rodriguez E, Rey L, González MV, Santos C, Rey M (2010). Detection of somaclonal variants in somatic embryogenesis-regenerated plants of Vitis vinifera by flow cytometry and microsatellite markers. Plant Cell, Tissue and Organ Culture 103:49-59. https://doi.org/10.1007/s11240-010-9753-1

Pethin D, Nakkanong K, Nualsri C (2015). Performance and genetic assessment of rubber tree clones in Southern Thailand. Scientia Agricola 72:306-313. https://doi.org/10.1590/0103-9016-2014-0354

Priyadarshan PM, Hoa TT, Huasun H, Gonçalves PS (2005). Yielding potential of rubber (Hevea brasiliensis) in suboptimal environments. Journal of Crop Improvement 14:221-247. https://doi.org/10.1300/J411v14n01_10

Rai MK, Phulwaria M, Gupta AK, Shekhawat NS, Jaiswal U (2012). Genetic homogeneity of guava plants derived from somatic embryogenesis using SSR and ISSR markers. Plant Cell, Tissue and Organ Culture 111:259-264. https://doi.org/10.1007/s11240-012-0190-1

Rahman MM, Mahmood M, Abdullah N, Shaharuddin NA, Parvin W (2017). Somatic embryogenesis and subsequent plant regeneration from zygotic embryo derived callus of rubber (Hevea brasiliensis Müell. Arg). Plant Tissue Culture and Biotechnology 27:51-61. 
Rathore MS, Mastan SG, Yadav P, Bhatt VD, Shekhawat NS, Chikara J (2016). Shoot regeneration from leaf explants of Withania coagulans (Stocks) Dunal and genetic stability evaluation of regenerates with RAPD and ISSR markers. South African Journal of Botany 102:12-17. https://doi.org/10.1016/j.sajb.2015.08.003

Ratnasingam J, Ramasamy G, Wai LT, Senin AL, Muttiah N (2015). The prospects of rubberwood biomass energy production in Malaysia. BioResources 10:2526-2548.

Rohela GK, Jogam P, Bylla P, Reuben C (2019). Indirect regeneration and assessment of genetic fidelity of acclimated plantlets by SCoT, ISSR, and RAPD markers in Rawwolfia tetraphylla L.: An endangered medicinal plant. BioMed Research International 2019:3698742. https://doi.org/10.1155/2019/3698742

Rohela GK, Jogam P, Mir MY, Shabnam AA, Shukla P, Abbagani S, Kamili AN (2020). Indirect regeneration and genetic fidelity analysis of acclimated plantlets through SCoT and ISSR markers in Morus alba L. cv. Chinese white. Biotechnology Reports 25:e00417. https://doi.org/10.1016/j.btre.2020.e00417

Sathish D, Vasudevan V, Theboral J, Elayaraja D, Appunu C, Siva R, Manickavasagam M (2018). Efficient direct plant regeneration from immature leaf roll explants of sugarcane (Saccharum officinarum L.) using polyamines and assessment of genetic fidelity by SCoT markers. In Vitro Cellular and Developmental Biology-Plant 54:399412. https://doi.org/10.1007/s11627-018-9910-5

Savita, Pati PK, Virk GS, Nagpal A (2015). An efficient somatic embryogenesis protocol for Citrus jambhiri and assessment of clonal fidelity of plantlets using RAPD markers. Journal of Plant Growth Regulation 34:309-319. https://doi.org/10.1007/s00344-014-9465-6

Sharma U, Rai MK, Shekhawat NS, Kataria V (2019). Genetic homogeneity revealed in micropropagated Bauhinia racemosa Lam. using gene targeted markers CBDP and SCoT. Physiology and Molecular Biology of Plants 25:581-588. https://doi.org/10.1007/s12298-018-00639-Z

Sirisom Y, Te-chato S (2014). Assessment of somaclonal variations of in vitro-plants derived from nodal culture of rubber trees by SSR markers. Songklanakarian Journal of Plant Science 1:7-12.

Srichuay W, Kalawong S, Sirisom Y, Te-chato S (2014). Callus induction and somatic embryogenesis from anther cultures of Hevea brasiliensis Müell Arg. Kasetsart Journal (Natural Science) 48:364-375.

Srichuay W, Te-chato $S$ (2015). Analyzing somaclonal variation in somatic embryo derived from in vitro anther culture of rubber tree (Hevea brasiliensis Müell. Arg.) by simple sequence repeat (SSR) marker and flow cytometry. Songklanakarin Journal of Plant Science 2:27-31.

Supriya R, Priyadarshan PM (2019). Genomic technologies for Hevea breeding. Advances in Genetics 104:1-73. https://doi.org/10.1016/bs.adgen.2019.04.001

Sushamakumari S, Asokan MP, Anthony P, Lowe KC, Power JB, Davey MR (2000). Plant regeneration from embryogenic cell suspension-derived protoplasts of rubber. Plant Cell, Tissue and Organ Culture 61:81-85. https://doi.org/10.1023/A:1006494404224

Thakur J, Dwivedi MD, Sourabh P, Uniyal PL, Pandey AK (2016). Genetic homogeneity revealed using SCoT, ISSR and RAPD markers in micropropagated Pittosporum eriocarpum Royle-An endemic and endangered medicinal plant.PLoS ONE 11:e0159050. https://doi.org/10.1371/journal.pone.0159050

Tisarum R, Samphumphung T, Theerawitaya C, Prommee W, Cha-um S (2018). In vitro photoautotrophic acclimatization, direct transplantation and ex vitro adaptation of rubber tree (Hevea brasiliensis). Plant Cell, Tissue and Organ Culture 133:215-223. https://doi.org/10.1007/s11240-017-1374-5

Uthup TK, Karumamkandathil R, Ravindran M, Saha T (2018). Heterografting induced DNA methylation polymorphisms in Hevea brasiliensis. Planta 248:579-589. https://doi.org/10.1007/s00425-018-2918-6

Venkatachalam P, Priya P, Amma CS, Thulaseedharan A (2004). Identification, cloning and sequence analysis of a dwarf genome-specific RAPD marker in rubber tree [Hevea brasiliensis (Muell.) Arg.]. Plant Cell Reports 23:327-332. https://doi.org/10.1007/s00299-004-0833-8

Wang TD, Huang TD, Huang HS, Hua YW (2017). Origin of secondary somatic embryos and genetic stability of the regenerated plants in Hevea brasiliensis. Journal of Rubber Research 20:101-116. https://doi.org/10.1007/BF03449145

Yang X, Blagodatsky S, Marohn C, Liu H, Golbon R, Xu J, Cadisch G (2019). Climbing the mountain fast but smart: Modelling rubber tree growth and latex yield under climate change. Forest Ecology and Management 439:5569. https://doi.org/10.1016/j.foreco.2019.02.028

Yao X, Chen X, Wang J, Zhou J, Cai M, Lin W (2017). Effect of clonal rootstocks on the growth and yield of Hevea rubber. Journal of Rubber Research 20:203-212. https://doi.org/10.1007/BF03449152 
Zhao H, Jia RZ, Zhu YJ, Guo AP, Zeng HC, Peng M (2015). Efficient induction, proliferation, and regeneration of rubber tree (Hevea brasiliensis Müell. Arg) via somatic embryogenesis. The Journal of Animal and Plant Sciences 25:134-140.

OPEN ACCESS

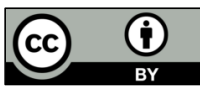

The journal offers free, immediate, and unrestricted access to peer-reviewed research and scholarly work. Users are allowed to read, download, copy, distribute, print, search, or link to the full texts of the articles, or use them for any other lawful purpose, without asking prior permission from the publisher or the author.

License - Articles published in Notulae Botanicae Horti Agrobotanici Cluj-Napoca are Open-Access, distributed under the terms and conditions of the Creative Commons Attribution (CC BY 4.0) License.

(c) Articles by the authors; UASVM, Cluj-Napoca, Romania. The journal allows the author(s) to hold the copyright/to retain publishing rights without restriction. 